\title{
SERUM LEVELS OF TOTAL PROTEIN, ALBUMIN AND GLOBULIN IN WOMAN WITH HYPEREMESIS GRAVIDARUM
}

\author{
BEGUM JA ${ }^{1}$, SULTANA R ${ }^{2}$, NAHER $\mathrm{S}^{3}$
}

\begin{abstract}
Background: Hyperemesis gravidarum is a severe type of vomiting in pregnancy which has significant effect on the health of mother and fetus. During this period various metabolic and endocrine changes occur in maternal body.

Objectives: The present study has been designed to observe the serum total protein,albumin and globulin in women with hyperemesis gravidarum.

Method: For this purpose 60 women with age ranging from 20 to 40 years were selected. The women with hyperemesis gravidarum were taken as case and Non pregnant nulliparous women $\&$ normal pregnant women during the first trimester of normal pregnancy were taken as control group. Each group consisted of 20 women. The total protein and albumin levels were measured in all study populations against the blank at wavelength of $530 \mathrm{~nm}$ and $620 \mathrm{~nm}$ in a colorimeter.

Results: The serum total protein and albumin levels were significantly $(p<0.001)$ higher in hyperemesis gravidarum and normal pregnant women during first trimester compared to control non pregnant nulliparous women.

Conclusion: Therefore the result of the present study reveals that higher levels of total protein, albumin and globulin in hyperemesis gravidarum in comparison to non pregnant nulliparous \& normal pregnant women due to increase thyroid hormones and also increases thyroxine - binding globulins.
\end{abstract}

Key words: Serum Total Protein, Serum Albumin, Serum Globulin, Hyperemesis Gravidarum

J Dhaka Med Coll. 2010; 19(1) : 58-60.

\section{Introduction:}

Hyperemesis gravidarum (HG) is a severe form of morning sickness, excessive pregnancy related nausea and vomiting that prevent adequate intake of food and fluid. ${ }^{1}$ The cause of hyperemesis gravidarum is unknown. The leading theories speculate that it is an adverse reaction to the hormonal changes in pregnancy particularly due to raised levels of $\alpha-\mathrm{hCG}$ (Human chorionic Gonadotrophin). ${ }^{2}$ It is a diagnosis of exclusion and may result in weight loss ,nutritional deficiency and abnormalities in fluid, electrolytes and acid base balance. ${ }^{3}$ During pregnancy, various metabolic and endocrine changes occur in maternal body to meet the demands of growing foetus. Nausea and vomiting of mild to moderate intensities are the common complaints among the women during their first trimester of normal pregnancy . ${ }^{4-6}$ It has been reported that hormonal change and metabolic demands during pregnancy result in alteration of different endocrine function including thyroid even in normal pregnancy. ${ }^{7-8}$ Again, such endocrine and metabolic changes are likely to be more in hyperemesis gravidarum. 6,9 Therefore, both the normal pregnancy as well as hyperemesis gravidarum may be associated with changes in thyroid activity. ${ }^{10}$ Serum levels of total protein, albumin and globulin in normal pregnancy have studied in our population and higher level of serum protein, albumin and globulin during first trimester were observed but the total protein, albumin globulin levels in hyperemesis gravidarum have not yet been studied in our country. Hyperemesis gravidarum is not uncommon in our country. Therefore, the present study has been designed to observe the changes in serum levels of total protein, albumin and globulin in

1. Associate Professor, Department of Physiology, Ibrahim Medical College, Dhaka

2. Assistant Professor, Department of Physioloy, Dhaka Medical College, Dhaka

3. Associate Professor, Department of Anatomy, Holy Family Red Crescent Medical College, Dhaka

Correspondence : Dr. Jesmin Ara Begum 
women with hyperemesis graviderum as well as normal pregnancy and non pregnant nulliparous woman.

\section{Materials and Methods:}

The present study was a case control study carried out to observe the serum total protein, albumin and globulin in patients suffering from hyperemesis gravidarum during the first trimester. Serum total protein, albumin globulin levels was also measured in apparently healthy non pregnant nulliparous women and normal pregnant women to observe the base line data in this population. For this purpose a total number of 60 women with age ranged from 20 to 40 years were selected. They were studied in three groups, each consisting of 20 subjects. Non pregnant nulliparous women and apparently healthy normal pregnant women without hyperemesis were taken as control and diagnosed patients suffering from hyperemesis gravidarum during the first trimester were taken as case.

All the pregnant subjects were selected from the Out Patient Department of Obstetrics and Gynecology, Dhaka Medical college Hospital (DMCH) Dhaka during the period of September, 1999 to June, 2000. Non pregnant subjects were selected from among friends, relatives and neighbors by personal contact.

Information regarding general condition, physical examination and complete obstetrical history of all the subjects were recorded in prefixed questionnaire. All the pregnant women in first trimester were not more than 13 weeks of gestation. The gestational age was determined by last menstrual period and were confirmed by ultrasonography .All the subjects belonged to lower middle and middle socioeconomic status. Before collection of samples the subjects were briefed about the objectives of the study and their verbal consents were taken. Blood samples were collected between 9 am - 11 am. Serum total protein, albumin globulin was measured in the Biochemistry Department of Bangabandhu Sheikh Mujib Medical University (BSMMU). Dhaka The estimation of serum total protein, albumin globulin were done to find out the availability of thyroxine- binding globulin. Statistical analysis was done by students unpaired ' $\mathrm{t}$ ' test .Computerized SPSS version was used for data analysis.

\section{Results:}

Table -I showed the mean $( \pm \mathrm{SE})$ serum total protein levels were $67 \pm 0.80,69 \pm 1.17$ and 74 $\pm 1.35 \mathrm{~g} / \mathrm{L}$ and serum albumin levels were 40 $\pm 0.37,41 \pm 0.45$ and $43 \pm 0.60 \mathrm{~g} / \mathrm{L}$ and serum globulin levels were $27 \pm 0.71,28 \pm 1.15$ and $31 \pm 1.37 \mathrm{~g} / \mathrm{L}$ in non pregnant nulliparous women, normal pregnant women and hyperemesis gravidarum respectively. Serum total protein were significantly higher in hyperemesis gravidarum compared to those of normal pregnant and non pregnant women nulliparous women also higher in normal pregnant women than that of non pregnant nulliparous women. The serum albumin is significantly increased in normal pregnant and hyperemesis gravidarum than that of non pregnant nulliparous women. The serum globulin is also increased in hyperemesis gravidarum than that of non pregnant nulliparous women.

\section{Table-I}

Serum total protein, albumin, globulin in study populations

\begin{tabular}{lccc}
\hline Groups & $\begin{array}{l}\text { Serum total } \\
\text { protein(g/L) } \\
(\text { Mean } \pm \text { SD) }\end{array}$ & $\begin{array}{c}\text { Serum } \\
\text { (Mean } \pm \mathrm{SD})\end{array}$ & $\begin{array}{c}\text { Serum } \\
\text { globulin(g/L) } \\
\text { (Mean } \pm \mathrm{SD})\end{array}$ \\
\hline $\mathrm{A}(\mathrm{n}=20)$ & $67 \pm 0.80$ & $40 \pm 0.37$ & $27 \pm 0.71$ \\
$\mathrm{~B}(\mathrm{n}=20)$ & $69 \pm 1.17$ & $41 \pm 0.45$ & $28 \pm 1.15$ \\
$\mathrm{C}(\mathrm{n}=20)$ & $74 \pm 1.35$ & $43 \pm 0.60$ & $31 \pm 1.37$ \\
\hline
\end{tabular}

Statistical Analysis

\begin{tabular}{lccc}
\hline Group & P value & P value & P value \\
\hline A vs B & $n s$ & $<0.05^{*}$ & $n s$ \\
A vs C & $<0.001^{* * *}$ & $<0.01^{* *}$ & $<0.05^{*}$ \\
B vs C & $<0.05^{*}$ & $n s$ & $n s$ \\
\hline
\end{tabular}

Statistical analysis done by unpaired Student ' $\mathrm{t}$ ' test $\mathrm{ns}=$ Not significant,${ }^{*} \backslash * * \backslash * * *=$ Significant

Group A: Nonpregnant nulliparous women Group B: Pregnant women at $1^{\text {st }}$ trimester

Group C: Hyperemesis gravidarum women at $1^{\text {st }}$ trimester. 


\section{Discussion:}

The serum total protein, albumin and globulin were statistically significant in hyperemesis gravidarum and non pregnant nulliparous women.Among them in hyperemesis gravidarum group we found serum total protein , albumin value were highly significant. The serum albumin was statistically significant in non pregnant nulliparous women and normal pregnant women group. In hyperemesis gravidarum and normal pregnant group serum total protein were found significant result . Similar results were found in other study.${ }^{11}$ They showed that higher value of serum total protein, albumin and globulin in hyperemesis gravidarum compared to those of normal pregnant and non pregnan nulliparous women .In this study, the mean $( \pm \mathrm{SE})$ serum total protein , serum albumin and serum globulin levels higer in normal pregnant women and hyperemesis gravidarum.than that of the non pregnant nulliparous women. Serum total protein were significantly higher in hyperemesis gravidarum compared to those of normal pregnant and non pregnant women nulliparous women also higher in normal pregnant women than that of non pregnant nulliparous women. The serum albumin is statistically significant in normal pregnant and hyperemesis gravidarum than that of non pregnant nulliparous women. The serum globulin is statistically significant in hyperemesis gravidarum than that of non pregnant nulliparous women.

\section{Conclusion:}

Hyperemesis gravidarum is a medical emergency and it needs immediate diagnosis and management to prevent the morbidity of the mother and also foetus. In present study increase in serum total protein, albumin and globulin levels during the first trimester of normal pregnancy and also in hyperemesis gravidarum was most likely due to the increase in serum TBG concentration (oestrogen - induced hepatic synthesis) during this period. This is further supported by the findings of the present study that there were increase in serum globulin concentration during first trimester of normal pregnancy which was more marked in hyperemesis gravidarum. Small size of the sample was an important limitation of the present study. so a large scale cross sectional study may required for more assurance .

\section{References:}

1. Elikim R, Abulufia O, Sherer DM. Hyperemesis Gravidarum. A current review American Journal of Perinatology 2000; 17 (4): 207 -218.

2. Hershman JM. Physiological and pathological aspects of the effect of human chorionic gonadotrophin on the thyroid. Best Pract Res clin Endocrinol Metab $2004 ; 18$ (2) : 249 -65.

3. Goodwin TM . Hyperemesis gravidarum .Obstet gynecol Clin N Am 2008 ; 35 : 401 - 417.

4. Swaminathan R, Chin RK, Lao TTH, Mak YT, Panesar NS Cockram CS. Thyroid fuction in hyperemesis gravidarum. Acta Endocrinol (Cophenh )1989;120: 155-60 .

5. Goodwin TM, Montoro M, Mestman JH, Pekary AE, Hershman JM.The role of chorionic gonadotropin in transient hyperthyroidism of hyperemesis gravidarum. J Clin Endocrinol Metab : $1992 ; 75$ : 1333-7.

6. Leylek OA, Cetin A, Toyaksi M, Erselcan T. Hyperthyroidism in hyperemesis gravidarum . Int J Gynecol Obstet 1996 ; 55 : 33-7 .

7. Harada A, Hershman JM Reed AW Braunstein GD , Dignam WJ, Derzko C, Friedman S, Jewelewiez R, Pekary AE . Comparison of thyroid stimulators and thyroid hormone concentrations in the sera of pregnant women. J Clin Endocrinol Metab 1979; 48: 793-7.

8. Bober SA, McGill AC, Tunbridge WMG. Thyroid function

hyperemesis gravidarum Acts Endocrinol 1986; 111: $404-10$.

9. Goodwin TM, Montorob M, Mestman JH. Transient hyperthyroidism and hyperemesis gravidarum . Clinical aspects .Am J Obstet Gynecol $1992 ; 167: 646$-52 .

10. Ballabio M, Poshyachinda M, Ekins R P . Pregnancy - Induced changes in thyroid function : Role of human chorionic gonadotropin as putative regulator of maternal thyroid. J Clin Endocrinol Metab 1991; 73(4): 824-31.

11. Jarfelt-Samsioe A, Eriksson B, Waldenstrom J, Samsioe G. Gynecol Obstet invest 1985 ; 19(4) $174-86$. 